УAK 34(09)

ББК 67.3

DOI 10.22394/1682-2358-2021-1-101-108

A.M. Ryabikov, postgraduate student of the Law Theory Department, Dubna State University, Chief State Customs Inspector of the Dubna customs post, Moscow Regional Customs

\section{PERSONNEL POLICY OF THE CUSTOMS SERVICE: THE PRESENT AND THE RUSSIAN EMPIRE PRACTICES IN THE 18TH CENTURY}

Personnel policy of the customs service of the Russian Empire in the 18th century is studied. Special attention is paid to the analysis of the previous period of the Moscow State in order to comprehensively and fully understand the ongoing processes of organizing the staffing of customs. An attempt is made to identify the cause-and-effect relationship between regulatory legal acts, personnel policy and counteraction to malfeasance.

Key words and word-combinations: customs service, official, counteraction to malfeasance.
A.M. Рябиков, аспирант кафедри теории права Государственного университета "Аубна", главньй государственный таможенноии инспектор таможенного поста Аубна Московской областной таможни (email: ryabikov.artyom@mail.ru)

\section{КААРОВАЯ ПОАИТИКА ТАМОЖЕННОЙ САУЖКБЫ: ОПЫТ РОССИЙСКОЙ ИМПЕРИИ ХVIII В. И СОВРЕМЕННОЙ РОССИИ}

Аннотация. Исследуется кадровая политика таможенной службы Российской империи XVIII в. Особое внимание уделяется анализу предшествующего периода Московского государства в целях всестороннего и полного понимания происходящих процессов организации укомплектования таможен. Предпринята попытка выявить причинно-следственную связь между нормативными правовыми актами, кадровой политикой и противодействием должностным преступлениям.

Ключевые слова и словосочетания: таможенная служба, должностное лицо, противодействие должностным злоупотреблениям.

ๆ рансформации, происходящие в мировой экономике, веАут к перезагрузке торгово-экономических отношений межАУ отАемьными странами и регионами мира, в связи с чем особое место в системе российского законодательства сегодня отведено таможенному праву.

Фелеральная таможенная служба России по состоянию на 2020 г. остается одним из кАючевых звеньев, являющихся источником формирования федерамьного 
бюджета: 4751,8 мцрА руб. - минус 977,16 мирА руб., или на 17,06\% к 2019 г. [1]. Естественно, коррупционные проявления [2] Аолжностных миц таможенной службы наиболее опасны и с уголовно-правовой, и с социальной стороны [3] .

Эффективное противодействие коррупции в таможкенных органах Российской Федерации сталкивается с рядом нерешенных до настояшего времени проблем и аспектов, которые требуют Аополнительной проработки.

Начальник Московской областной таможни (МОТ) генерал-майор таможенной службы В.А. Романовский в поздравлении с 10-летним юбицеем со дня образования таможни справедливо отмечает, что во все времена таможенники стояли на страже страны. Высокий профессионацизм, компетентность и преданность своему делу являются надежкным гарантом защиты экономических интересов государства.

В связи с этим грамотная кадровая политика государства в сфере таможенной службы в отношении граждан, претендующих на замещение Аолжностей сотрудников и федеральных государственных гражданских скужащих (ФГГС) таможенных органов, позволяет уже на первоначальном этапе (принятии на службу) минимизировать возможные риски и выявить предрасположенность кандидатов к коррупционным правонарушениям. Такая работа осуществляется не только отделом каАров, в частности психологом, но и Аолжностными циџами службы противодействия коррупции (СПК).

Попытаемся исследовать вопрос организаџии поступления на службу в таможкенные органы в XVIII в, предъявмяемые требования к кандидатам и иное на основе нормативных правовых актов, включенных в 4-26 тома первого собрания Полного собрания законов Российской империи (1700-1801 гг.) [4] , Российского государственного архива Аревних актов и актов, собранных в библиотеках и архивах Российской империи (т. IV). За основу взят именно этот период, так как на более ранних этапах развития Российского государства применять терминологию, связанную с планомерной и последовательной кадровой политикой, в теоретическом смысле было бы не вполне корректно [3, с. 104]. Следует отметить, что в XVIII в. происходиц поиск наиболее оптимальной модели организации укомпцектования системы таможенной службы Российской империи.

Многие частные аспекты, касающиеся развития в Российской империи планомерной кадровой политики, явмяются следствием анализа неблагоприятной ситуации в кадровом укомплектовании таможенного ведомства и общих процессов, происходивших в Московском государстве.

Аля понимания полной картины необходимо осветить кадровый аспект таможенной службы Московского централизованного государства, а

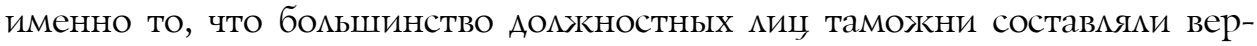
ные целовальники, социальная принадлежность которых варьировалась в широком диапазоне: среднее купечество, посадские июди и крестьяне. В 
качестве общих требований, предъявмяемых к кандидатам, были наличие личной свободы и обязанность нести государственную повинность [5, с. 245]. Как видим, требования довольно специфические и касались не столько деловых качеств и способностей кандидатов, сколько их социального и правового статуса.

Кроме того, закреплялась обязательность возрастного ценза в АваАцать мет по Соборному уложению, так как именно с этого возраста в ст. 1 гл. XIV «О крестном целовании, а в ней 10 статей» было прописано: «...всяких чинов русским мюдям доведется по судным делам изо всех приказов крест целовать: и им или за них людям их крест целовать в разных исках трижды. А возрастом бы те мюди были, кому крест целовать, в двадџать цет, а меньше двадџати мет не целовать и ко кресту таких не припускать» [6, с. 71]. Ценза грамотности к кандидатам на должности служителей не преАъявцялось, вслеАствие чего подавцяющее большинство цемовальников были мибо вовсе неграмотными, мибо малограмотными.

Особенностью каАровой политики таможенной службы до начала XVIII в. явцялся тот факт, что при приеме на государственную службу большее значение отводилось религиозному аспекту, чем способностям и знаниям кандидатов (от этого и происходит название «верная служба»), которая по своему духу была больше похожа на повинность. Естественно, такое положение дел не могло оставаться неизменным по причине унификации и усложнения таможенных процедур, и назрела потребность пересмотра вопроса о кадровом укомплектовании системы таможенной службы, что, собственно, и произошло в период правления Петра I.

При этом следует отметить, что качественные изменения, которые произошли в первой половине XVIII в., не имели бы столь положительного эффекта, если бы отсутствовали фундаментальная база и предшествующие мероприятия, которые были заложены и проведены в первоочередном порядке в период правления царя Алексея Михайловича. В большей степени они повлияли на трансформацию в организационно-правовом аспекте деятельности таможенной службы мишь в Российской империи.

Отметим также, что имелся и положительный исторический опыт каАровой политики Московского государства. Речь идет о крестоџеловании при приеме на службу таможенных голов и целовальников, то есть своего рода психологического инструмента воздействия на подсознание кандидата в силу высокой роли рекигии и веры в жизни общества. В периоА царствования Петра I крестоџелование было заменено на присягу, которая приносицась при вступлении на должность таможенного служащего. Важно также, что кандидаты помимо присяги домжны были ознакомиться с текстами правоохранительных указов, запрещающих змоупотребления [7, с. $136 ; 8$, c. 194].

В настоящее время гражданин, принятый на службу в таможенные органы, принимает присягу в соответствии со ст. 19 Федерального закона 
«О службе в таможенных органах Российской Федерации» [9]. Вместе с тем данное требование не относится к Федеральной государственной гражданской службе, которая в своей повседневной деятельности, помимо Федерального закона «О государственной гражданской службе Российской Федерации», преимушественно руководствуется Кодексом этики и служебного поведения должностных миц таможенных органов Российской Федерации.

Кадровая политика XVIII в. в целом характеризовалась возможностью быстрого карьерного роста Амя способных и достойных профессионалов своего дела, что и сегодня может рассматриваться как положительный опыт [10, с. 384-385].

Наиболее принципиальные изменения в системе центрального управмения таможенной службы в петровский период начались с миквидации приказной системы, которая к тому времени уже изжила себя и не соответствовала реалиям.

В связи с активным строительством новой столицы - Санкт-Петербурга (1703 г.), развитием торговли со странами Европы, Северной войной (1700-1703 гг.) изменяется и роль таможни на граниџе Российского государства. Санкт-Петербург, благодаря мичному покровительству Петра Великого [11, с. 264], становится важным экономическим, научным и культурным центром Российского государства, крупным транспортным узмом, а к 1724 г. - ведущим морским портом империи. Иными словами, город превращается в «цитадель жизни и ведущую торговую артерию империи.

Вместе с тем, осознавая значимость возможныш рисков при осуществлении Аолжностными циџами таможни своих обязанностей, а также негативный оттенок государственной службы как повинности, Петр I в Указе 1724 г. заключил, что содержать таможенных служителей без жалования опасно дмя таможенных сборов [12, с. 28]. Кроме того, как отмечается в работах Н.В. Козмовой, кратковременность службы и незаинтересованность в ней посаАских АюАей препятствоваАи созданию обученных каАров в такой обцасти государственного хозяйства, которому правитецьство отвоАило все большую роль в денежных накоплениях [13, с. 87].

Формирование новой модели каАрового состава таможен впосмедствии осложницось такой пробцемой, как профессиональная подготовка каАров. Строгий подбор штата таможенных служащих входиц в сферу компетенции Коммерџ-коммегии. Так, п. 17 регламента преАписывал: «САужитемям таможенным как в сборе пошлинном, так и в прочем обхождении поступать по сочиненным вновь регулам и тарифу... число мюдей достойных, а ежели иные фискалы усмотрят за кем из них преступления указов, и том донесено будет, по которым Аоносам чинить розыск и надмежащее решение» $[14$, с. 245]. Аанный орган управления имел право предлагать Сенату «годных мюдей» на Аолжности «обер-директоров, обер-инспекто- 
ров, пошииных инспекторов, пошлиных сборщиков и иных таможкенных служителей» [12, с. 17]. Как видим, формулировка весьма расплывчатая и

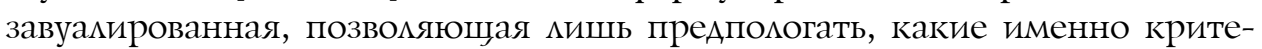
рии использовацись дия отбора кандидатов на государственную службу.

Вместе с тем анализ архивных документов свидетельствует о четко регламентированной таможенной проџедуре оформления, Аолжностных обязанностях и ответственности таможенников - к примеру, в п. 32 закреплялось, что товар не полагается открывать и развязывать, пока производится досмотр [15, с. 239]. Таможенным служащиме все потери или убытки - как в выгрузке, так и в загрузке товаров самим платить надлежит, если они их без совершенного основания ици подиинной причины учиници» [15, с. 238].

Через руки таможенников на морской и сухопутной таможнях СанктПетербурга проходиц огромный поток грузов, что требовацо соответствую-

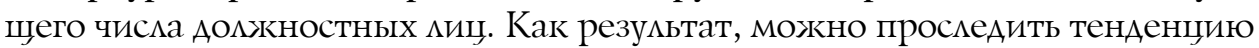
значительного увеличения штатного расписания таможни в соответствии с объективной потребностью прослежкивается в архивных Аокументах. Постепенно преАпринятые Петром Великим мероприятия Аали свои плоды: система таможенного контроля и делопроизводства увеличивала свою эффективность, совершенствовацись способы раскрытия таможенных преступлений со стороны торговцев. По воспоминаниям современников, отмечалось, что иностранные торговцы и гости столицы характеризовали

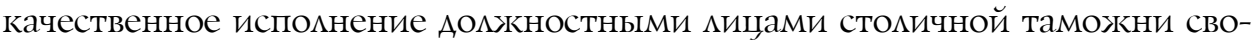
их служебных обязанностей, превосходное знание иностранных языков, вежливость и образованность. Аанный факт не мог не радовать и тешить самолюбие императора, детищем которого была реформированная СанктПетербургская таможня.

Новая модель укомплектования таможенной службы Российской империи характеризовалась следующими особенностями: Аобровольность, бессрочность, возмездность (жалование согласно штатному расписанию). Привлекательные условия таможенной службы нашли быстрый отклик у населения в отмичие от «верной» службы.

В результате Санкт-Петербургская таможня стала экспериментальным центром новой кадровой политики Российской империи в XVIII в., а покученный опыт организации бым позАнее использован на всей территории государства. 20-30-е годы XVIII в. характеризуются принятием штатных расписаний в портовых таможнях, а позднее - и в сухопутных пограничных. В частности, впервые по Указу Сената 1724 г. закреплялось положение, в котором прописывалось впредь об определении к тому сбору непременных

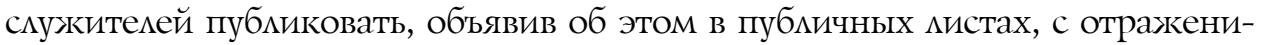
ем жалования в соответствии со штатным расписанием [16, с. 265] .

Переход к новой кадровой организации таможен выявия проблему подбора кадров, к ним стали предъявцяться определенные требования, 
а именно происхожкение, образование, квалификация, мичные качества кандидатов. ОАнако на службу могли быть приняты только свободные слои населения. При этом возник парадокс, так как само государство относимось с подозрением к мюбым цично свободным и грамотным кандидатам и запрашивало "рекомендаџию» Аомжностного миџа Аибо состоятельного и уважаемого жителя. Аанное обстоятельство бымо отменено мишь в 1734 г. [17, с. 352]. Принцип штатной организации кадров пограничных таможен внедрялся уже позднее, на основе полученного опыта [18, с. 55].

Заслуживает особого внимания деятельность в 80-х годах XVIII в. руководителя Санкт-Петербургской портовой таможни А.Н. Радищева, который добросовестно осуществлял выполнение своих Аолжностных обязанностей, служиц во благо экономической безопасности Российской империи, активно боролся с проявлениями коррупщии [12, с. 113] .

В целом в Российской империи этого периода наметилась положкительная тенденция нормативном регулировании деятельности и институџионального становления каАровой политики таможенной службы.

При проведении парамлелей с XXI в. можкно проследить преемственность в системе кадрового укомплектования таможенной службы. К сожалению, положительный опыт Московского государства и Российской империи не в полной степени учитывается в современных реалиях, в частности, недостаточный уровень выдемяемого государством денежного содержания на государственных служащих [19], которые изначально явмяются зоной риска по причине наличия у них властных полномочий и тем, как они ими воспользуются. Но и здесь нет однозначного решения, поскольку весьма проблематично предусмотреть всевозможные варианты развития конкретных событий в деятельности должностных миџ и таможенной службы, и преАставителей Аругих государственных структур [3, с. 107].

Анализ нормативных документов (Пцана мероприятий ФТС России на период 2021-2024 годов по реализации Стратегии развития таможенной службы Российской Федераџии до 2030 года [20], протоколов совещаний у руководителя ФТС России В.И. Булавина, планов таможни по противоАействию коррупции на 2021-2023 гг., сводок по совершенным должностным преступцениям таможенных служащих) позволяет заключить, что в отношении подбора кандидатов и государственных служащих проводится жесткая каАровая политика.

ОАнако, к сожалению, борьба, как правило, ведется со следствием, а не причиной должностного преступления - недостаточным материальным обеспечением государственных служащих, отсутствием стимулирования их добросовестного исполнения служебных обязанностей в связи с высокой ответственностью и большой загруженностью [19]. Указ Президента РФ о повышении окмадов ФГГС на 3\% с 1 октября 2020 г. [21] особой роли не сыграл, так как в денежном выражении эта сумма нивелировалась ростом цен и инфмяцией. 
Историко-правовой опыт каАровой политики и противодействия АоАжностным преступлениям в таможенной служббе в XV-XVIII вв. подтвержАает, что достойное материальное обеспечение государственных служащих служит стимулом Аобросовестного и качественного исполнения должностных обязанностей при минимизации возможных рисков нарушений действующего законодательства со стороны должностных миџ таможенной службы.

Представцяется, что эффективными методами стимулирования кадров и повышения престижности прохождения службы в таможенных органах, а также мерами профилактики коррупџионных правонарушений может быть ряд конкретных мероприятий.

Во-первых, в связи с тем, что ФГГС значительно уступают в правовом статусе сотрудникам (в предоставлении служебного жилья и др.), цемесообразно рассмотреть вопрос о переводе части первых, например, АОмжностных Аиц центров электронного декларирования (ЦЭА) и постов фактического контроля (ТПФК), «поА погоны» с учетом требований к кандидатам в рамках Федерального закона от 21 июля 1997 г. № 114-ФЗ «О службе в таможенных органах».

Во-вторых, следует стимулировать карьерный рост сотрудников при Аобросовестном исполнении служебных обязанностей при отсутствии фактов дисциплинарного взыскания и совершения коррупџионных правонарушений. При этом можно учесть положительный опыт созАания «молоАежных советов» Аля выявления потенџиальных мидеров при назначении на ту или иную Аолжность.

В-третьих, необходимо актуализировать подход к соџиальным гарантиям: предусмотреть выдемение путевок в подведомственные санатории с учетом результатов работы должностного мица за год, преАусмотреть возможность досрочного выхода на пенсию Аля миџ, получивших звание «Ветеран таможенной службы».

B-четвертых, рациональна оптимизация численности служащих за счет изменения структуры ФТС России и сокращения «промежуточных» органов, таких как региональные таможенные управления с учетом «Стратегии - 2030» [20] и создания 16 ЦЭА, с одновременным приемом на государственную службу квалифицированных специалистов и выпускников Российской таможенной академии для передачи опыта.

В-пятых, требуется профессиональная работа психолога с кандидатами, претендующими на замещение должностей, и должностными циџами таможенных органов, в том числе с применением на практике психофизиомогического исследования с помощью полиграфа.

\section{Библиографический список}

1. Сайт Федеральной таможенной службы России. URL: http://www.customs.ru

2. Федоренко Д.Н. Актуальные вопросы оценки эффективности подразделений по 
противодействию коррупции таможенных органов России // Таможенная политика России на Дальнем Востоке. 2017. № 2 (79). С. 98-106.

3. Рябиков А.M. Становление института уголовной ответственности должностных лиц таможенной службы в Московском государстве // Вестник Поволжского института управления. 2020. Т. 20, № 1. С. 103-110.

4. Полное собрание законов Российской империи: Собрание первое: с 1700 по 1801 г. СПб., 1830.

5. Балковая В.Н. Таможенная служба в системе управления Российского государства: XVI-XVIII вв.: историко-правовой аспект: дис. ... д-ра юрид. наук: 12.00.01. М., 2017.

6. Соборное уложение 1649 г. // ПСЗРИ. Т. І, № 1. С. 71-73.

7. О воспрещении взяток и посулов и о наказании за оное: Именной указ от 24 дек. 1714 г. // ПСЗРИ. Т. V, № 2871. С. 136.

8. О наказании за взятки и лихоимства: Указ Правительствующего сената от 21 мая 1720 г. // ПСЗРИ Т. VI. № 3586. С. 194.

9. О службе в таможенных органах Российской Федерации» (с изм. и доп.): Федер. закон от 21 июля 1997 г. № 114-Ф3 // СЗ РФ. 1997. № 30. Ст. 3586.

10. Об определении для поимки ввозимых в Россию и вывозимых из оной запрещенных товаров сверх объездчиков Главного надзирателя: Указ Правительствующего сената от 6 июля 1755 г. // ПСЗРИ. Т. XIV, № 10431. С. 384-385.

11. О взимании в Архангельском порту с привозным иностранных товаров пошлин четвертую долю больше против С. Петербургского порта: Именной указ об объявлении из Сената // ПСЗРИ. Собр. 1. Т. 7 (1723-1727), № 4475 С. 264-265.

12. Таможенная служба Санкт-Петербурга. 1703-2003 / под общ. ред. В.И. Вьюнова. СПб., 2003.

13. Козлова Н.В. Российский абсолютизм и купечество в XVIII в. (20-е - начало 60-х гг.). M., 1999.

14. Регламент Коммерц-Коллегии от 31 янв. 1724 г. // ПСЗРИ. Собр. 1. Т. 7 (17231727), № 4453 C. 241-249.

15. Морской торговый регламент и Устав от 31 янв. 1724 г. // ПСЗРИ. Собр. 1. Т. 7 (1723-1727), № 4451 С. 233-241.

16. Об истребовании из магистрата купеческого звания людей для сбору пошлин в портах и вывозе на предбудущее время вольноопределяющихся для определения в таможни к означенным должностям: Указ Сената от 15 февр. 1724 г. // ПСЗРИ. Собр. 1. Т. 7 (1723-1727), № 4477. С. 265.

17. Об определении в пограничные таможни инспекторов и цолнеров из приказных людей без порук и об отдаче сборных пошлинных сумм помесячно в губернские рентереи или воеводские канцелярии: Указ Правительствующего сената от 17 июня 1734 г. // ПСЗРИ. Т. ІХ, № 6588. С. 352-353.

18. Об учреждении таможни в Белгороде для сбора внутренних и тарифных пошлин: Указ Правительствующего сената от 10 мая 1749 г. // ПСЗРИ. Т. ХІІІ, № 9613. С. 55.

19. О государственной гражданской службе Российской Федерации: Федер. закон от 27 июля 2004 г. № 79-Ф3 (с изм. и доп.) // Российская газета. 2004. № 162.

20. СПС «КонсультантПлюс». URL: http://www.consultant.ru/document/cons_doc_ LAW_368703/

21. О повышении окладов месячного денежного содержания лиц, замещающих должности федеральной государственной гражданской службы: Указ Президента РФ от 13 июля 2020 г. № 455. URL: https://www.publication.pravo.gov.ru 